\title{
Effect of Perceived Ease of Use, Word-of-Mouth Communication, and Brand Image on Decision to Use Lazada E-Commerce Services
}

\author{
Randy Imam Pratama*; Dian Dewi Megadini; Tanti Kusriandini \\ Faculty of Business, Bina Nusantara University, Indonesia \\ Email: randy.pratama001@binus.ac.id
}

http://dx.doi.org/10.18415/ijmmu.v6i1.533

\begin{abstract}
The rapidly growing communication, media and information technology and the widespread development of global information infrastructure has influenced the ways and patterns of business activities in the trade industry, social and political governance. Indonesia is one of the countries that has the largest internet growth after China and India. This growth is likely to form online buying and selling transactions. It is supported by a survey conducted by APJII (Association of Indonesian Internet Service Providers) about Internet Users in Indonesia in 2016 that the most frequently visited commercial content was online shop (62\%) or equal to 82.2 million. Visitors and big opportunities for online shops have an impact on the emergence of more e-commerces whose goods or products sold come from the website or application itself without giving opportunity or place for other sellers to sell their products. Based on the data from CNN Indonesia, the number of Lazada app's downloaders is in first place followed by its competitors Tokopedia and Bukalapak. The abundance of e-commerce in Indonesia creates increasingly fierce competition. Many e-commerce applications or websites provide display menu that makes it easier for users to shop, quality and complete items, varied price ranges, and trusted image of the e-commerce.
\end{abstract}

Keywords: Word-of-Mouth; Brand Image; E-Commerce; Lazada

\section{Introduction}

Indonesia is one of the countries that has the largest internet growth after China and India. This growth is likely to form online buying and selling transactions. It is supported by a survey conducted by Association of Indonesian Internet Service Providers (APJII) about Internet Users in Indonesia in 2016 that the most frequently visited commercial content was online shop $(62 \%)$ or equal to 82.2 million.

The development of the internet makes it easy for e-commerce to be a place of sale and purchase since the goods or products come from the website itself and do not give chances or places for other sellers to sell their products. The emergence of e-commerce creates a very tight competition. Many ecommerce services provide the best service, including the ease of use, the quality and completeness of the goods sold, the varied price ranges, the trusted image of e-commerce, and so forth. 
Based on the data from CNN Indonesia, the number of Lazada app's downloaders is in first place followed by its competitors Tokopedia and Bukalapak. Lazada is in the first rank because it is an online shopping center that offers various types of products consisting of electronics, books, children's toys, baby equipment, medical devices, beauty products, household appliances, traveling equipment, and sports equipment.

Lazada provides various kinds of needs with a simple display. It makes it easy for users to use these services through the website or application. Perceived ease of use is a belief about the decisionmaking process. If someone feels that the information system is easy to use, he/she will use it. On the other hand, if someone believes that the information system is not easy to use, he/she will not use it.

There are many Lazada users who get information about its products from various sources of information including word of mouth communication. It makes it easier for users to provide information from where they got information about Lazada; that is from the closest people like friends, family, colleagues or relations. Thus, if they already have confidence in the information or advice, commonly, they will act based on the reference.

Brand image sourced from experience illustrates that involvement between consumers and companies has occurred. Such involvement will occur if the company can satisfy consumers. In purchasing decisions, consumers really choose products that are considered to be in accordance with their needs and desires in which a product brand depends on the image attached. Thus, companies must be able to provide the best products that are in accordance with customers' needs and desires. Brand image has a very important role because it can distinguish a company or a product from another. The objective of this research is to analyze the effect of perceived ease of use (X1), word of mouth communication (X2), and brand image (X3) variables simultaneously on the decision to use (Y).

\section{Literature Review \\ 2.1. E-Commerce}

Bryan A. Garner stated that "e-commerce covers the practice of buying and selling goods and services through online consumer services on the Internet. E-commerce, shortened from electronic commerce, has become a popular prefix for other terms associated with electronic transactions". Basically, the definition of e-commerce is the purchase and sale of goods and services by using online computer services on the Internet (Barakatullah et al., 2005).

E-commerce according to Khan (2016) is electronic commerce or buying and selling of goods and services on the Internet. In addition to buying and selling, many people use the internet as an information source to compare prices or see the latest products offered before making purchases online or through traditional stores.

Internet and e-commerce are closely related to developed countries. But internet and e-commerce can be used well in developing countries. For ideal business purposes, e-commerce is a revolution in business practices (Khan., 2016). Electronic commerce is a concept that explains the process of buying and selling or exchanging products, services, and information through computer networks including the internet (Khan., 2016). E-commerce according to Rajasetar and Agarwal (2016) is a type of business model, or segment of a larger business model, which allows companies or individuals to do business through electronic networks; commonly the Internet. E-commerce is one of the main criteria of Information Technology and communication revolution in the economic field (Nanehkaran., 2013). Through virtual markets, physical stores that do not sell unique or rare items allow e-commerce access runs uniquely. 
E-commerce fundamentally changes the way of economy and business run. E-commerce allows companies to find new ways to expand the market where they compete, to attract and retain customers by adjusting products and services to their needs, and to restructure their business processes with the aim of providing products and services more efficiently and effectively (Azadi., 2011). However, e-commerce services can shift their focus from building the customer base to increasing revenue growth and profitability which must reevaluate their current business strategy (if any) and develop strategies that provide a clear path to profitability.

E-commerce services in Indonesia are currently being chosen more because the development of the internet in Indonesia is very well supported by telecommunication sophistication on smartphones. So, this e-commerce service makes it easier for consumers to shop without having to come to various stores. In addition to facilitating consumers to buy goods, e-commerce services also make it easier for sellers to sell goods without having to have a physical store. Good e-commerce services can be reflected through testimonials from buyers about the speed of the goods arriving at the hands of consumers and the quality of the goods sold, the prices offered by sellers and the speed of sellers to respond to buyers' questions. They also consider whether the e-commerce service can be good or not so that it can compete with other e-commerce services.

Based on a survey conducted by CNN Indonesia in 2017, Lazada application has the highest number of downloads compared to Tokopedia and Bukalapak. It means that Lazada has a large user so that it can compete with other e-commerce. There are several factors that influence why Lazada is one of the e-commerce services with the highest number of downloads. It may be influenced by perceived ease of use, word of mouth communication and brand image.

\subsection{Perceived Ease of Use}

Perception is the process of individual understanding of objects, phenomena, and events based on observation, experience, and supervision obtained through interpretation using five senses. Thus, perception is the process of an individual recognizing, comparing, classifying, and interpreting an object that he/she sees and feels. According to Monisa (2012), perceived ease of use is a level of someone believing that the use of technology only requires a little effort. Ease means having no difficulty or does not require hard effort when using the technology. Perception about the ease of use of this technology refers to the individual belief that information technology systems can facilitate their activities without much effort.

Research conducted by Doshi (2018) shows that perceived ease of use has a positive correlation with e-commerce services because e-commerce services in the form of sites and applications are easy to use. Users feel easy so that they become proficient at operating it. If they understand and master it, users will feel flexible to interact with it.

Research conducted by Surendran (2012) found that perceived ease of use has been widely used to help understand and explain user behavior in an information system. The ease of use of information systems has an effect on users to use the system.

Perceived ease of use is defined as the degree to which someone believes that using a particular system can improve the performance of his/her work (Redzuan et al., 2016). In the organizational context, a system that is high in perceived ease of use is one that users believe will have a positive use. 
Redzuan (2016) explained that it is the extent to which a development is considered a perception of ease of use. Then, Redzuan (2016) found results that allow users to communicate with systems that are useful for certain people.

\subsection{Word of Mouth Communication}

Word of mouth communication is the most effective form of promotion. Satisfied customers will be the spokesperson for the company's products more effectively and convincingly than any type of advertisement. According to Kotler \& Armstrong (2012) word of mouth communication is a personal communication about the product between the buyer and the people around them. Word of mouth communication is a form of conversation about a product, between one person with another person in which there is a message that is sometimes not realized by the information giver or by the recipient of the information.

Research conducted by Thi and Tao (2017) showed that electronic word of mouth communication has a positive impact on purchase intention. Their analysis also concluded that electronic word of mouth communication has an indirect impact on purchase intention, brand image, and perceived value.

Another study conducted by Luong (2017) found that electronic word of mouth communication greatly affects brand image and intentions of Vietnamese consumers when choosing tourism products. It means that whenever customers want to find a brand or have the intention of buying a product, they will pay attention to electronic word of mouth communication.

In addition, a study conducted by Omer et al (2014) in the International Journal of Arts \& Sciences Conference: Las Vegas, Nevada, USA concluded that there is a significant positive correlation between electronic word of mouth communication on brand image and purchase intention.

Research conducted at Ain Shams University in Egypt by Elseidi and El-Baz (2016) concluded that eWOM can positively or negatively shape brand image and attitude in the consumer mindset. Finally, the effect of electronic communication of word of mouth communication on consumer purchase intention is significant and can bring positive changes in consumer attitudes to the brand when they receive information from trusted sources.

Similar findings were also obtained in the UK. A professor at Newcastle University Filieri (2015) in a research on e-WOM found that information and normative influences play an important role in determining how consumers value the quality of a product.

Research conducted by Haijli et al (2014) shows that potential buyers to search for WOM socially for new products based on information provided by other consumers through assessment and review.

Regarding Lazada service as the object of this research, based on the research findings from several researchers it is concluded that users will use Lazada e-commerce services after getting reviews from other users. Service users will trust to use Lazada if they have received a good review results from the previous user.

\subsection{Brand Image}

According to Kotler and Keller (2012), a brand, as a name, term, sign, symbol, or design, or combination of them, is intended to identify the goods or service of one seller or group of sellers and to 
differentiate them from those of competitors. Based on these definitions, it can be concluded that the brand is a "sign in the form of images, names, words, letters, numbers, arrangement of colors or a combination of these elements that have distinguishing features and are used in the trading of goods and services.

Other researchers showed that there is a significant correlation between brand image and purchasing decisions (Shukla., 2011). Charo et al (2015) found that brand image has a significant and positive effect on buyers' decisions. Jallilvand and Samiei (2012) and Torlak et al (2014) found that brand image has a moderating effect on purchasing decisions.

Brand image on Lazada e-commerce services is considered to be very important because the brand becomes the identity of the service. In addition, the brand will also grow consumer loyalty. Consumer loyalty will provide benefits for e-commerce parties because consumers will often use these services. If consumers are familiar with e-commerce services, they will not easily move to other ecommerce services. The more consumers satisfied with the quality of products sold, services and ease of use, the higher the selling value of a brand. Brand image according to Elseidi and El Baz's (2016) research is a brand image concept that has attracted the attention of academics and practitioners because its importance affects many marketing outcomes. Other researchers also mention that their brand and image usually have important competitive advantages that create significant additions and values for a company (Ait-Sahalia., 2004). In addition, the research conducted by Shukla (2011) shows that brand image is an important mediator in the correlation between normative interpersonal influences and classy brands in the intention to buy.

Other research states that brand image is a very important competitive advantage that helps create value through brand differentiation, decisions to buy, build and significant value for organizations (Kala and Chaubey, 2018). Brand image according to Shahrinaz et al (2016) consists of attributes and benefits offered by a brand to distinguish it from other competitors.

Thus, brand image becomes an important indicator whose ability can fulfill its social function of self-expression and self-presentation (Elseidi and El Baz., 2016). Brand image is one of the considerations for someone using Lazada e-commerce services to shop because brand image is something that is reviewed first by the customer. By looing at the brand image, they will get an idea of the contents of the service.

Research conducted by Anwar et al (2011) at the University of Islamabad, defines brand image as the sum of brand associations in consumer memory that leads to brand perception and brand associations including brand attributes, brand benefits, and brand attitudes.

\subsection{Purchase Decision}

Purchase decision can be considered as one of the main components of consumer cognitive behavior that show to what extent someone intends to buy a particular brand or product (Hosein., 2012). According to Spears and Singh (2004) purchasing decisions are consumers' conscious plans to try or buy the products. Previous research conducted by Moe and Fader (2004) found that purchasing decisions are a key indicator of the success of online advertising. Many studies agree that consumer attitudes toward a product or brand affect purchase intentions (Ajzen., 2001). In addition, other researchers showed a significant correlation between brand image and purchase intention (Shukla., 2011).

Purchasing decisions can be considered as one of the main components of consumer cognitive behavior that shows a conscious plan for consumers to try or buy products (Spears \& Singh., 2004). Other 
researchers show that there is a significant correlation between brand image and purchasing decisions (Shukla., 2011). Charo et al (2015) found that brand image has a significant and positive impact on buyers' decisions. Jallilvand and Samiei (2012) and Torlak et al (2014) found that a brand image of a brand has a moderating effect on purchasing decisions. Purchasing decisions are also defined as decisions to act or psychological actions that show an individual's behavior towards a product (Samin et al., 2012).

Purchasing decisions indicate the desires of consumers based on their experiences, preferences and externals on the environment to gather information, and make purchasing decisions (Schiffman and Kanuk., 2000). A research conducted by Zhang et al (2004) investigated the direct effects of brand image and service quality on brand image and purchasing decisions for private label brands and revealed that it has a positive correlation to buying intentions that are affected by the brand image.

\section{Methododology}

This research applied multiple regression analysis, which is a tool to predict the value of the effect of two independent variables or more on one dependent variable. It aimed to prove whether or not there is a functional or causal correlation between two or more independent variables (Nugroho., 2005).

In addition, the research sampling was carried out using non-probability sampling technique. This technique did not use opportunity selection procedures but relies on the personal judgment of the researcher. The research sampling was based on the consideration that respondents had used Lazada ecommerce services. The samples were chosen by the author as the data source needed for this research.

This research applied error tolerance (e) of $10 \%$ and the population (n) of 10,000,000 Lazada application users. The following is the calculation of the number of samples using the Slovin formula (1):

$$
n=\frac{10.000 .000}{1+10.000 .000(0.1)^{2}}=99.99
$$

Based on the results of these calculations, the research samples are amounted to 99.99 which was then rounded up to 100 users.

The data collection of in this study used questionnaires to Lazada users. The respondents were people who have used Lazada e-commerce services. Data collection was carried out through a questionnaire submitted to each selected respondent. By using a questionnaire personally, researchers can relate directly to the respondent and can provide explanations as needed. The research data were obtained directly from filling out the questionnaire by the respondents. The questionnaire of this research consisted of questions of each indicator of the research variables.

The questions on the questionnaire were made on a Likert scale. The Likert scale is a scale that is widely used. It required respondents to mark the degree of agreement or disagreement with each of a series of statements regarding the stimulus object. Generally, a measurement uses five response categories that range from "strongly agree" to "strongly disagree" (Malhotra, 2009). Scale 1-5 is used to obtain numerical data and given a score or value for the category of questions with "strongly disagree" or "strongly agree answers". 


\section{Findings}

\subsection{Validity Test}

Table 1 Validity test results of the research variables

\begin{tabular}{lcccc}
\hline Variables & Item Number & $\boldsymbol{r}_{\boldsymbol{i x}}$ & r-table & Description \\
\hline \multirow{3}{*}{ Perceived Ease of Use(X1) } & 1 & 0.808 & 0.361 & Valid \\
& 2 & 0.847 & 0.361 & Valid \\
& 3 & 0.896 & 0.361 & Valid \\
& 4 & 0.825 & 0.361 & Valid \\
\hline \multirow{3}{*}{ Word of Mouth } & 1 & 0.666 & 0.361 & Valid \\
Communication & 2 & 0.652 & 0.361 & Valid \\
& 3 & 0.729 & 0.361 & Valid \\
& 4 & 0.628 & 0.361 & Valid \\
& 5 & 0.717 & 0.361 & Valid \\
& 6 & 0.809 & 0.361 & Valid \\
& 7 & 0.804 & 0.361 & Valid \\
Brand Image (X3) & 8 & 0.748 & 0.361 & Valid \\
& 1 & 0.737 & 0.361 & Valid \\
& 2 & 0.672 & 0.361 & Valid \\
& 3 & 0.707 & 0.361 & Valid \\
& 4 & 0.593 & 0.361 & Valid \\
& 5 & 0.677 & 0.361 & Valid \\
Purchase Decision (Y) & 6 & 0.675 & 0.361 & Valid \\
\hline & 1 & 0.820 & 0.361 & Valid \\
& 2 & 0.789 & 0.361 & Valid \\
& 3 & 0.582 & 0.361 & Valid \\
& 4 & 0.702 & 0.361 & Valid \\
\hline
\end{tabular}

Source: Processed primary data (2018)

Validity test was carried out to find out whether or not the questions given are quite valid. Based on the test that had been carried out whose results are listed in Table 1, it was found that the r-table values of all questions are more than 0.30 which were considered as valid.

\subsection{Reliability Test}

Table 2 Reliability test results of the research variables

\begin{tabular}{lcc}
\hline Variables & Cronbach's Alpha $(\alpha)$ Values & Description \\
\hline Perceived Ease of Use $(\mathrm{X} 1)$ & 0.859 & Reliable \\
Word of Mouth Communication (X2) & 0.863 & Reliable \\
Brand Image (X3) & 0.786 & Reliable \\
Purchase Decision (Y) & 0.713 & Reliable \\
\hline
\end{tabular}

Source: Processed primary data (2018)

Reliability test is a test used to measure a questionnaire containing indicators of research variables. From the results of output in Table 2, the entire Cronbach's alpha values of the research were 
greater than 0.7. Therefore, it is concluded that all research instruments are reliable. It proves that this research can be continued.

\subsection{Multiple Linear Regression Analysis}

Table 3 Multiple linear regression test

\begin{tabular}{|c|c|c|c|c|c|c|}
\hline \multirow[t]{2}{*}{$\overline{\text { Model }}$} & & \multicolumn{2}{|c|}{ Unstandardized Coefficients } & \multirow{2}{*}{$\begin{array}{c}\text { Standardized } \\
\text { Coefficients } \\
\text { Beta }\end{array}$} & \multirow{2}{*}{$\mathrm{t}$} & \multirow{2}{*}{ Sig } \\
\hline & & $\mathrm{B}$ & Std. Error & & & \\
\hline \multirow{4}{*}{1} & (Constant) & 1.048 & 2.356 & & .445 & .657 \\
\hline & X1 & .477 & .110 & .361 & 4.321 & .000 \\
\hline & $\mathrm{X} 2$ & .216 & .041 & .430 & 5.204 & .000 \\
\hline & X3 & -.046 & .075 & -.049 & -.615 & .540 \\
\hline
\end{tabular}

Source: Processed data, SPSS (2018)

Based on Table 3, a regression equation can be formulated to determine the effect of independent variables on dependent variable as follows:

$\mathrm{Y}=\mathrm{a}+\mathrm{b}_{1} \mathrm{X}_{1}+\mathrm{b}_{2} \mathrm{X}_{2}+\mathrm{b}_{3} \mathrm{X}_{3}+\mathrm{e}$

$\mathrm{Y}=1.048+0.477 \mathrm{X} 1+0.216 \mathrm{X} 2-0.046+\mathrm{e}$

Description:

Y: Decision to use

e: Standard error

$\mathrm{X}_{1}$ : Perceived ease of use

$b_{1}$ : Regression coefficient of perceived ease of use

$\mathrm{X}_{2}$ : Word of mouth communication

$b_{2}$ : Regression coefficient of word of mouth communication

$\mathrm{X}_{3}$ : Brand image

$\mathrm{b}_{3}$ : Regression coefficient of brand image

\subsection{Statistical t-Test (Partial)}

Table 4 Statistical t-Test (Partial)

\begin{tabular}{|c|c|c|c|c|c|c|}
\hline \multicolumn{7}{|c|}{ Coefficients ${ }^{\mathrm{a}}$} \\
\hline \multirow[t]{2}{*}{ Moc } & & \multicolumn{2}{|c|}{ Unstandardized Coefficients } & \multirow{2}{*}{$\begin{array}{c}\text { Standardized } \\
\text { Coefficients } \\
\text { Beta }\end{array}$} & \multirow[t]{2}{*}{$\mathrm{t}$} & \multirow[t]{2}{*}{ Sig. } \\
\hline & & $\mathrm{B}$ & Std. Error & & & \\
\hline \multirow{4}{*}{1} & (Constant) & 1,048 & 2,356 & & ,445 &, 657 \\
\hline & $\mathrm{X} 1$ & 477 & 110 &, 361 & 4,321 &, 000 \\
\hline & $\mathrm{X} 2$ &, 216 & 041 &, 430 & 5,204 &, 000 \\
\hline & $\mathrm{X} 3$ &,- 046 & 075 &,- 049 &,- 615 &, 540 \\
\hline
\end{tabular}

Source: Processed data, SPSS (2018) 


\subsection{Effect of Variable X1 (Perceived Ease of Use) on Variable Y (Purchase Decision)}

The variable $\mathrm{X} 1$ has a t-calculate of 4.321 (greater than t-table 1.667) or a significance value of 0.000 (smaller than alpha 5\%). It means that variable X1 (perceived ease of use) has a significant effect on variable $\mathrm{Y}$ (purchase decision) at alpha 5\%. X1 variable (perceived ease of use) has a significant effect on variable $\mathrm{Y}$ (purchase decision).

Current internet advancements make it easy to pay at Lazada. There are several options to pay such as bank transfers, credit cards, on-the-spot payment, payment through mini market that has collaborated with Lazada, and even through installments (credit). This convenience is one reason consumers want to shop at Lazada. In addition, Lazada services also often offer discount offers such as flash sale on certain days, free shipping in a minimum specified amount, and other attractive offers. The convenience provided by Lazada triggered potential customers to continue to use Lazada as a place to buy all the needs they want.

\subsection{Effect of Variable X2 (Word of Mouth Communication) on Variable Y (Purchase Decision)}

The variable X2 has a t-calculate of 5.204 (greater than t-table 1.667) or a significance value of 0.000 (smaller than alpha 5\%). It means that variable X2 (word of mouth communication) has a significant effect on variable $\mathrm{Y}$ (purchase decision) at alpha 5\%. Variable X2 (word of mouth communication) has a significant effect on variable $\mathrm{Y}$ (purchase decision).

The marketing activities carried out by Lazada are strong enough so that it can affect consumers' interest in shopping at Lazada. It happened because the reviews of previous customers were quite good and the rating of the seller was also good so that the interest of consumers to purchase was very strong. The more consumers give a review stating that they are satisfied to shop at Lazada and satisfied with the items he buys in terms of packaging, authenticity and quality of goods, the better marketing through word of mouth communication.

Word of mouth communication affects consumers to talk about, promote, and sell company brands to others. Lazada's services are quite strong because Lazada provides a review column for buyers of the items they have purchased on the Lazada application or website containing good reviews and satisfying consumers. Therefore, someone will be interested in buying products at Lazada because they read the reviews in the provided columns.

\subsection{Effect of Variable X3 (Brand Image) on Variable Y (Purchase Decision)}

The variable X3 has a t-calculate of -0.049 (smaller than t-table 1.667) or a significance value of 0.000 (bigger than alpha 5\%). It means that variable X3 (brand image) does not have a significant effect on variable Y (purchase decision) at alpha 5\%. Variable X3 (brand image) does not have a significant effect on variable $\mathrm{Y}$ (purchase decision).

The research findings found that brand image does not affect purchasing decisions. Although there are many downloaders of the Lazada application, these users do not necessarily make purchases at Lazada. Lazada's e-commerce service brand still ranks under Shopee e-commerce services, because there may be several sellers on Lazada that are not trusted; thus, affecting Lazada's brand image as an ecommerce service. In addition, it includes poor service during product shipping; for instance, products do not arrive on time as scheduled, bad and unclear seller services in answering questions from prospective buyers, the absent of up-to-date notification for product shipping, and non-original goods that are that are 
sold at high prices so that consumers felt that they have been cheated. These things have an effect on Lazada's brand image. If the problem is solved properly, it will affect Lazada's brand image better.

\subsection{Statistical F-Test (Simultaneous)}

Table 5 Statistical F-Test (Simultaneous)

\begin{tabular}{|rl|r|r|r|r|r|}
\hline \multicolumn{1}{|l|}{ Model } & & Sum of Squares & \multicolumn{1}{c|}{$\mathrm{df}$} & Mean Square & F & \multicolumn{1}{l|}{ Sig. } \\
\hline \multirow{4}{*}{1} & Regression & 269,207 & 3 & 89,736 & 21,899 &, $000^{\mathrm{b}}$ \\
& Residual & 393,383 & 96 & 4,098 & & \\
& Total & 662,590 & 99 & & & \\
\hline
\end{tabular}

Source: Processed data, SPSS (2018)

Based on the results of the SPSS output above, the value of F-calculate is 21.899. Next, it was continued by looking for the value of F-table (k-1; n-k). It obtained F-table value of 3.09. It was found that the F-calculate value was 21.899 which was greater than the F-table of 3.09. It can be concluded that the independent variables X1, X2, and X3 simultaneously affect the dependent variable (Y).

\subsection{Coefficient of Determination (R2)}

Based on the results of testing that has been carried out, the coefficient of determination has a value of 0.406 or $40.6 \%$. It shows that the ability of the independent variables to explain the variance of the dependent variable is $40.6 \%$, which means that there are $59.4 \%$ of the variance of the dependent variable explained by other factors. Based on this interpretation, the value of $\mathrm{R}$ square is between 0 and 1 . Based on the results of the SPSS output, the value of F-calculate is 21.899 . Next, it is continued by looking for the value of F-table $(\mathrm{k}-1 ; \mathrm{n}-\mathrm{k})$. It obtains F-table value of 3.09. Then, the F-calculate value is 21.899 greater than the F-table of 3.09. It is concluded that the independent variables $\mathrm{X} 1, \mathrm{X} 2$, and X3 simultaneously affect the dependent variable (Y).

\section{Discussion}

\subsection{Effect of Perceived Ease of Use Variable on Purchase Decision Variable}

Perceived ease of use has a significant effect on purchasing decision because Lazada provides easy payment to consumers and often provides flash sales and discounts on certain days. This convenience makes consumers decide to shop at Lazada. It is expected that Lazada can maintain the service and even be able to innovate with it so that it can attract consumers to shop at Lazada e-commerce services.

These findings are similar to the research conducted by Doshi (2018) which shows that perceived ease of use has a positive correlation with e-commerce services because it is an easy-to-use site and application. When users feel that it is easy, they become proficient and can operate it easily. When it is clear and understandable, users feel flexible to interact with the service. This is also the same as the findings of the research obtained by Surendran (2012) who mentioned that perceived ease of use has been 
widely used to help understand and explain user behavior in an information system. The ease of use of information systems has an effect on users in using the system.

\subsection{Effect of Word of Mouth Communication Variable on Purchase Decision Variable}

Word of mouth communication has a significant effect on purchase decisions that is caused by good reviews provided by consumers who have previously shop at Lazada. Therefore, it affects other consumers to shop there. If the seller can maintain the quality and service, the word of mouth communication will be better and attract many consumers to buy products at the seller. Moreover, Lazada, as the party that provides facilities to the sellers, must continue to maintain the sellers at Lazada to provide better services and products so that consumers feel satisfied shopping at Lazada.

This is similar to the findings of a research conducted by Luong (2017) who found that electronic word of mouth greatly affects brand image and customer's intentions in Vietnam. Research conducted in Egypt by Elseidi and El-Baz (2016) concluded that eWOM can positively or negatively shape brand image and attitude in the consumer mindset. Finally, the effect of word of mouth electronic communication on consumer buying intentions is significant and can bring positive changes in consumer attitudes to the brand when consumers receive information from trusted sources.

In addition, there are also researches that have the same findings as this research that were conducted by researchers from Newcastle University, Washington State University, Auburn University by Haijli, Lin, Featherman, and Wang (2014). In their research, they showed that buyers tend to search for social WOM for new products based on information provided by other consumers through assessment and review.

\subsection{Effect of Brand Image Variable on Purchase Decision Variable}

Brand image does not significantly affect purchase decision because there are still some sellers who sell non-original items so consumers feel disappointed to shop at Lazada. It has made Lazada's brand image worse. In addition, there are a number of other things such as the poor service of the seller in replying to questions from prospective buyers so that potential customers feel unappreciated. This will also adversely affect Lazada's brand image.

In previous researches, other researchers showed that there is a significant correlation between brand image and purchasing decision (Shukla, 2011). Charo et al (2015) found that brand image has a significant and positive effect on purchase decision. Jallilvand and Samiei (2012) and Torlak et al (2014) found that brand image has a moderating effect on purchasing decisions. That is also the same as the research conducted by Zhang et al (2004) who investigated the direct effects of brand image and service quality on brand image and purchase decision for private label brands. They revealed that there is a positive correlation in purchase intention that is affected by brand image. The research findings are different from previous studies because there are still some non-original items that make its brand image worse. 


\subsection{Simultaneous Effect between Perceived Ease of Use (X1), Word of Mouth Communication (X2), and Brand Image (X3) Variables on Purchase Decision (Y)}

Based on the results of the F-test, the F-calculate value is $21.899>$ F-table 3.09 with a significance level of $0.000<0.05$. It is concluded that there is a linear correlation between the independent variables $\left(\mathrm{X}_{1}, \mathrm{X}_{2}, \mathrm{X}_{3}\right)$ and the dependent variable $(\mathrm{Y})$ as a whole.

\section{Conclusion}

The results of the determination test mean that the effect of the independent variables (as a whole) on the dependent variable is $40.6 \%$ and the remaining $59.4 \%$ is affected by other factors outside of this research.

\section{References}

Ait-Sahalia, Y., Parker, J. and Yogo, M. (2004). Luxury Goods and the Equity Premium. Journal of Finance, 59(6): 2959-3004.

Ajzen, I. (2001). Nature and Operation of Attitudes, Annual Review of Psychology, 52(1): 27-58.

Anwar, A., Gulzar, A., Sohail, F. B., \& Akram, S. N. (2011). Impact of Brand Image, Trust and Affect on Consumer Brand Extension Attitude: The Mediating Role of Brand Loyalty. International Journal of Economics and Management Sciences, 1(5): 73-79.

Azadi, S. (2011). Strategies for Commpetitive in Electronic Commerce. Emerging Markets Journal, 1: 5969.

Charo, N., Sharma, P., Shaikh, S., Haseeb, A., \& Sufya, M. Z. (2015). Determining the Impact of Ewom on Brand Image and Purchase Intention Through Adoption of Online Opinions. International Journal of Humanities and Management Sciences, 3(1): 41-46.

Doshi, P. V. (2018). Relationship of Perceived Ease Use and Perceived Usefulness on Usage of Ecommerce site. International Journal of Academic Research and Development. Faculty of Commerce University of Baroda: India.

Elseidi, R. I., \& El-Baz, D. (2016). Electronic Word of Mouth Effects on Consumers' Brand Attitudes, Brand Image and Purchase Intention: An Empirical Study in Egypt. The Business \& Management Review, 7(5): 268.

Filieri, R. (2015). What Makes Online Reviews Helpful? A Diagnosticity-Adoption Framework to Explain Informational and Normative Influences in e-WOM. Journal of Business Research, 68(6): 12611270.

Hajli, N., Lin, X., Featherman, M., \& Wang, Y. (2014). Social Word of Mouth: How Trust Develops in the Market. International Journal of Market Research, 56(5): 673-689.

Moshrefjavadi, M. H., Dolatabadi, H. R., Nourbakhsh, M., Poursaeedi, A., \& Asadollahi, A. (2012). An Analysis of Factors Affecting on Online Shopping Behavior of Consumers. International Journal of Marketing Studies, 4(5): 81. 
Jalilvand, M. R. dan Samiei, N. (2002), The Effect of Electronic Word of Mouth on Brand Image and Purchase Intention: An Empirical Study in the Automobile Industry in Iran, Marketing Intelligence \& Planning, 30(4): 460-476.

Kala, D., \& Chaubey, D.S. (2018). Impact of Electronic Word of Mouth on Brand Image and Purchase Intention Towards Lifestyle Products in India. Pacific Business Review International, 10(9): 135-144.

Khan, A. G. (2016). Electronic Commerce: A Study on Benefits and Challenges in An Emerging Economy. Global Journal of Management and Business Research.

Kotler, P., \& Armstrong, G. (2013). Principles of Marketing: Fourteen Edition. Person Education.

Kotler, P., \& Keller, K. (2012). Marketing Management 13, New Jersey. Pearson Prentice Hall, Inc., New Jersey.

Luong, D. B. (2017). The Impact of Electronic Word of Mouth on Brand Image and Buying Decision: An Empirical Study in Vietnam Tourism, International Journal of Research Studies in Management, Saigon University, Ho Chi Minh City University of Food Industry: Vietnam.

Malhotra, N. K. (2009). Riset Pemasaran Pendekatan Terapan. Edisi keempat. Jilid 2: PT. Indeks Kelompok Gramedia.

Monisa, Martina. (2013). Persepsi Kemudahan dan Kegunaan OPAC Perpustakaan Unair (Study Deskriptif Menilai Persepsi Kemudahan dan Persepsi Kegunaan OPACOleh Pengguna di Perpustakaan Universitas Airlangga), Jurnal Ilmu Informasi dan Perpustakaan FISIP Unair: Surabaya.

Moe, W. W., \& Fader, P. S. (2004). Dynamic Conversion Behavior at E-Commerce Sites. Management Science, 50(3): 326-335.

Nanehkaran, Y. A. (2013). An Introduction to Electronic Commerce. International Journal of Scientific and Technology Research, 2(4): 190-193

Schiffman, L. G., \& Kanuk, L. L. (2000). Consumer Behavior, 7th. NY: Prentice Hall, 15-36.

Torlak, O., Ozkara, B. Y., Tiltay, M. A., Cengiz, H., \& Dulger, M. F. (2014). The Effect of Electronic Word of Mouth on Brand Image and Purchase Intention: An Application Concerning Cell Phone Brands for Youth Consumers in Turkey. Journal of Marketing Development and Competitiveness, 8(2): 61.

Redzuan, N. I. N., Razali, N. A., Muslim, N. A., \& Hanafi, W. N. W. (2016). Studying Perceived Usefulness and Perceived Ease of Use of Electronic Human Resource Management (e-HRM) with Behavior Intention. International Journal of Business, 1(2).

Rajasekar, D., \& Agarwal, S. (2016). A Study on Impact of E-Commerce on India's Commerce. International Journal of Development Research, 6: 7253-7256.

Rezvani, S., Dehkordi, G. J., Rahman, M. S., Fouladivanda, F., Habibi, M., \& Eghtebasi, S. (2012). A Conceptual Study on the Country of Origin Effect on Consumer Purchase Intention. Asian Social Science, 8(12): 205.

Irwan, S. (2016). Relationship and Impact of e-WOM and Brand Image Towards Purchase Intention of Smartphone ?. Journal of Scientific Research and Development, 3(5): 117-124. 
Shukla, P. (2011). Impact of Interpersonal Influences, Brand Origin and Brand Image on Luxury Purchase Intentions: Measuring Interfunctional Interactions and a Cross-National Comparison. Journal of World Business, 46(2): 242-252.

Spears, N.\& Singh, S. N. (2004). Measuring Attitude Toward the Brand and Purchase Intentions. Journal of Current Issues and Research in Advertising, 26(2): 53-66.

Surendran, P. (2012). Technology Acceptance Model: A Survey of Literature. International Journal of Business and Social Research, 2(4): 175-178.

Zhang, L., Tan, W., Xu, Y. \& Tan, G. (2012). "Dimensions of Consumerse Perceived Risk and Their Influences on Online Consumers"e Purchasing Behaviour", Communications in Information Science and Management Engineering, 2(7): 8-14.

\section{Copyrights}

Copyright for this article is retained by the author(s), with first publication rights granted to the journal.

This is an open-access article distributed under the terms and conditions of the Creative Commons Attribution license (http://creativecommons.org/licenses/by/4.0/). 